Volume 13

Issue 3 September

Article 10

September 1986

\title{
Building Citizen Support for Planning at the Community Level
}

Barry Checkoway

University of Michigan

Follow this and additional works at: https://scholarworks.wmich.edu/jssw

Part of the Civic and Community Engagement Commons, Social Work Commons, and the Urban Studies and Planning Commons

\section{Recommended Citation}

Checkoway, Barry (1986) "Building Citizen Support for Planning at the Community Level," The Journal of Sociology \& Social Welfare: Vol. 13 : Iss. 3 , Article 10.

Available at: https://scholarworks.wmich.edu/jssw/vol13/iss3/10

This Article is brought to you by the Western Michigan University School of Social Work. For more information, please contactwmu-scholarworks@wmich.edu.

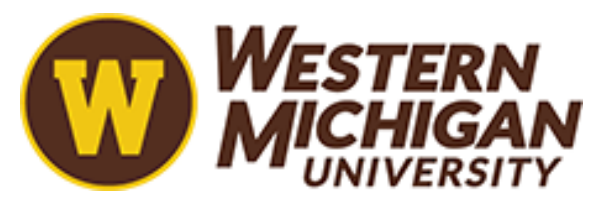




\title{
Building Citizen Support For Planning \\ At The Community Level
}

by

\author{
Barry Checkoway \\ University of Michigan \\ School of Social Work
}

\begin{abstract}
Planning practice is changing. Previous years of economic growth contributed to an increase in federal, state, and local planning agencies, in addition to regional and special purpose bodies with territorial or functional responsibilities. In times of growth, planning was viewed by many as a type of urban engineering and applied social science characterized by objective fact-finding and the so-called rational model. Leading texts emphasized technical research methods and "hard data" analysis, while government guidelines described scientific application of facts (Krueckeberg and Silvers, 1974; Spiegel and Hyman, 1978). Planners were akin to technical experts who analyzed data for other people who then considered alternatives and made decisions. implementation was largely a matter of choice among technical alternatives. The plan, as a statement of reasoned deliberation and general public interest, was considered capable of generating support throughout the cormunity. If some planners criticized contradictions between the rational model and actual practice, or used planning as a vehicle for power redistribution and social change, they were by no means typical in the field (Beyle and Lathrop, 1970; Burchell and Sernlieb, 1978; Boyer, 1983; Davidoff, 1965).
\end{abstract}

Today, planning operates in a changing context. Economic recession has replaced growth and reduced development. This has exacerbated conditions in central cities and metropolitan areas, 
some of which are slowing, even declining in population, employment, and other measures of urban activity. Private groups blame government for economic problems and planning agencies for a range of ills. They mobilize substantial resources, mount campaigns to shape public attitudes, and elect representatives who reduce the size of government and agencies. Planners no longer expect to generate widespread support, but instead may struggle for survival in the face of power (Checkoway, 1983; Clavel, et al., 1980; Forester, 1982).

It is, therefore, no surprise that planning agencies may not, in fact, implement their plans. Analysts have documented the shortcomings of implementation in diverse arenas for years (Alter man, 1983; Bardach, 1977; Lynn, 1980; Mazmanian and Nienaber, 1979; Thompson, 1981). The surprise for many planners is that the problem is not implementation alone but also their very future in the community. Austerity policies and adversarial power challenge planners to recognize sociopolitical change and develop the capacity to deal with the years ahead.

This paper analyzes methods of building citizen support for planning at the community level. It draws on research and practice in several fields and includes cases of planners and agencies that apply innovative or exemplary methods. It does not suggest that suggest that these planners are typical in the field, or that these methods alone are sufficient to alter the context of practice. It does suggest that planning operates in a changing context, and that planners who want to influence implementation -and, perhaps, agency survival - must go beyond rational models to build support for planning at the community level.

\section{Methods of Building Citizen Support}

Building citizen support involves methods to plan programs, services, and resources with influence and implementation in mind. It assumes that planning operates in a context of politics, that planning decisions are usually in the hands of other people, and that planners wishing to infiuence decisions must apply methods appropriate to this context. Practitioners apply methods in public or private settings; at national, state, and local levels; and in housing, health, human services and other fields. There is no single notion that characterizes all forms of practice. 
There is nothing new about agency attempts to build support, but previous efforts often contradicted stated aims or produced uneven results. For example, agencies for years have composed governing bodies, boards and comittees to provide representation, involve citizen interests, and build support for plans, but these bodies have not always broadly represented the area population or involved individuals accountable to diverse constituencies in the cormunity (Checkoway, 1981; Mannor and Morone, 1980).

Other agencies have adopted subarea planning aimed to decentralize decisions and programs to territorial subunits and local participants, but subarea planning has often served administrative ends and deconcentrated functions within real decentralization to local residents (Checkoway, 1984; Kasperson and Brietbait, 1974). Other agencies have employed programs and methods to improve communications, involve individuals, and activate participation in planning, but most agencies have not adopted singular driving objectives for participation. They have instead favored safe methods like public hearings that satisfy minimal federal requirements and provide public relations without transferring power to or increasing the support of citizens (Arnstein, 1969; Checkoway, 1982). Exceptional agencies have represented interests and activated citizens with fervor, but most have not mobilized forces or built significant support (Checkoway, 1981).

What methods could help build citizen support for planning at the community level? The following are not the only methods, but are among the most important.

\section{Formulate Strategy}

Strategy is the science and art of mobilizing resources toward goals. It includes steps to set goals and priorities, identify issues and constituencies, develop structure and organization, take actions and evaluate results. It involves choice and sequence, staging and timing, and several styles and roles. Strategy shows a commitment to think ahead, anticipate alternatives, and achieve results (Booth, 1977; Bryson and Delbecq, 1979; Steiner, 1979).

Corporate leaders formulate strategy to help assure success, but planning officials tend not to think or act strategically 
(Baum, 1983; Peters and Waterman, 1982). However, Bleiker (1978) instructs planners how to design programs and apply techniques that develop support for plans that are controversial, unpopular, and difficult to implement. Staples (1984) describes strategic analysis to help build winning organizations. Bryson, Freeman, and Roering (1984) describe cases of strategic planning in public agencies, including a health service which identifies issues, analyzes alternatives, identifies internal and external environmental factors, forms task forces around issues and selects alternatives for implementation. These cases are exceptional but provide lessons nonetheless.

\section{Ident ify Issues}

Issues express specific social concerns and affect people in deeply felt ways. They appeal to particular constituencies with concrete proposals, provide tactical handles and multiple phases, and help build support for organizations. Which is the most salient issue? Who are the constituencies? What tactics and actions will work? Where will it lead? Booth (1977) instructs planners to "cut" issues in ways which relate to constituencies, although many planners produce comprehensive plans with vague goals for some general public. Such plans may serve functions but diffuse constituencies and exacerbate implementation. Such goals may be good but too vague to stire imaginations and more constituents to action.

How can planners cut issues which build citizen support? Lancourt (1979) challenges planners to consider salience and self interest in identifying issues for implementation. She assumes that people will act in the name of public responsibility and civic duty when it is in their self interest to do so. Roche (1981) describes planners who took goals from agency plans, listed groups with identifiable stakes and political strength, defined issues in terms of target groups, and used media to make issues come alive to these groups. For example, they built support to labor leaders by seeking their input and demonstrating how proposed plans would maintain wages and fringes and minimize disruption to employees. They did not justify esoteric formulas or sell rationality, but appealed to self interest and, as a result, leaders voted overwhelmingly to support the plan. 
This does not suggest that issues alone will generate support. On the contrary, Krumholz (1975, 1982) describes planners who framed comprehensive plans in terms of specific issues and constituencies, but had uneven results because they lacked resources to activate participation or overcome opposition in the community. Issues are important but insufficient to build support without other methods.

\section{Develop Constituencies}

Building an organization involves caring about those who are affected. Whose issue is it? What do they see as their stake? Are they organizable? Constituencies are those who are affected by issues and may show support. Planners who represent some diffuse public interest rather than target supportive constituencies may do so at risk to themselves.

Constituencies are not random relationships but result from efforts to identify and develop them (Barkdoll, 1983; Beneviste, 1977; Lipschultz, 1960; Staples, 1984). In one innovative agency, for example, planners identify major constituency groups, invite them to select representatives to the governing body, and assist representatives in building support in the community. In another, they create an independent organization with business, labor, professional, civic and consumer group members who build support beyond the governing body (Checkoway, 1981). In yet another, they analyze agency goals in terms of individual and group opposition, and then develop relationships and provide services to selected ones in expectation of loyalty and support in return (Roche, 1981).

\section{Educate the Public}

Citizens cannot be expected to support planning without understanding their problems and stake in the process and agency addressing them. The challenge is not public relations but popular education and cormunity development. It is an older conception of planning in which planners help people to learn about themselves and their communities as well as to understand the problems they face, and facilitate a process to involve people in the decisions which affect their lives (Freire, 1968; Goulet, 1971). 
Planners recognize the importance of public education, but tend to emphasize public information programs including "safe" methods like annual reports, newsletters, and public hearings to inform the general public rather than target specific constituencies (Checkoway, 1981, 1982; Texas Municipal League, 1975; Winholz, 1968). Others lack educational objectives or rely upon obscure media like legal notices in newspapers, although studies show that these are among the least effective ways to communicate with the public (Rosener, 1975; Sinclair, 1977). Yet others use technical language which exacerbates difficulty in understanding and gives the impression that only professionals can present an adequate response (Friedman, 1973). No wonder some people may lack awareness or understanding of planning agencies, ignore calls for participation, or withdraw the ir support (Checkoway, 1979).

Several practitioners provide suggestions regarding strategy and skills of popular education (Joslyn-Scherer, 1980; Gordon, 1978). Who are the people to be reached? What issues will educate and develop constituencies? What media are appropriate and what language will communicate? There is a history of popular education in earlier agencies -- including exhibits and displays in department stores and shopping centers, and popularizations of technical documents for mass distribution (Glenn, et al., 1947; Scott, 1969). One innovative agency provides extensive public notices of hearings, public service announcements, radio and television appearances, direct mass mailings, leaflet distribution, public presentations, and personal outreach by staff and board members, in addition to publishing a monthly multicultural, multilanguage newspaper targeted to specific constituencies. The newspaper has become the leading vehicle for planning information in the area. Another agency sponsors a speakers' bureau that facilitates board and staff member presentations to local groups, helps agency representatives exchange ideas and receive feedback, and facilitates board member education and leadership training. Another agency conducts training programs, publishes educational guides to develop leaders and activate citizens, and reaches the public through weekly columns in newspapers, public service announcements, and regular appearances on television and radio (Checkoway, 1981). These agencies view education as central to their mission, to involve individuals and groups, and bring planning closer to the community. 


\section{Find and Make Leaders}

Citizen leaders show cormitment to goals, develop a following, and stand up for planning in the community. They also attend board meetings and chair comittees, but these are vehicles for leadership rather than leadership itself. Many planners retreat from the process by which leaders are selected or developed. Instead, they consider leadership in the narrow context of meetings, or believe that some given process satisfactorily produces leaders to represent the population and account to constituencies, or creates "appropriate" leadership by promoting people who hold positions in established institutions. However, leadership appropriation also may promote people who are unrepresentative, unaccountable, or uncommitted to plans, or who simply lack time to act like leaders.

There is no a prior $i$ justification for overrepresentation of business and other private interests in planning agencies. The ir traditional overrepresentation is purely political and difficult to defend by leadership or implementation criteria. It would be ironic if agencies appropriated leaders with relatively little commitment to planning, although this happens in some communities.

How can planners find and make leaders? Bradley (1981) describes an innovative agency that seeks to identify potential leaders, recognize their talent, and develop their skills. He assumes that any citizen can function well when given proper support, that planners have responsibility to foster development, and that if citizens are not acting like leaders, planners may not be doing their job properly. Kimmey (1981) describes centers authorized to assist and consult with participants through orientation, reference, and other programs. These include training to overcome disparities in knowledge, present technical information and participation techniques, and develop leadership capacity and political skills. Others provide curricula to teach board members about the political economy of planning ideologies of the principal actors, distribution of benefits and problems of special clients and subpopulation groups, alternative delivery systems and elements of planned social change. Lessons focus on skills with citizens and enlist their participation, set goals and formulate strategies, develop self confidence and think independently (Checkoway, 1981; Strauss, et al., 1976). There is no science of 
leadership development in planning, but if planners themselves do not take this responsibility, then who will?

\section{Establish Relations with Influentials}

These key actors are able to exercise power and influence decisions that affect the agency. They are not random relationships but result from a plan for establishing or maintaining them. Who are the influentials? What are their political resources? What is their place in various institutions? What are the possible paths of influence?

How can planners identify, maintain and develop relations with influentials? Tait, Bokemeir and Bohlen (n.d.) describe positional, reputational, decision making and other methods to identify those who may gain from agency activity and marshall their support. They also identify possible opponents, analyze their interests, and anticipate was to channel their involvement constructively. Roche (1981) analyzes ways to cultivate relationships through issue-based appeals to self-interests, or special efforts to involve influentials in decisions, or priority responses to requests for information and assistance in return for support. He describes planners who discuss issues with influentials to explain their stake, respond quickly to requests from public officials, labor unions, chambers of commerce, media, and community groups with large constituencies, and participate in political elections for officials who return favors by defending planning. There is no lack of published advice on personal or political approaches to win friends and influence others (Carnegie, 1936; Riordan, 1963; Twa in, n.d.).

\section{Build Coalitions}

Coalitions are working relationships to collaborate together and influence outcomes. They serve to mobilize individuals or groups around a common program and generate power to fulfill the program which is developed. They also help individuals share resources, help one another, and build mutual support. They may be short-term, shifting, or relatively permanent. Some are little more than occasional meetings, while others operate with staff of their own. They are important for individuals seeks to build support beyond the reach of what each could accomplish alone (Dluhy, 1981; Pearce, 1983; Kahn, 1980; Schakowsky, n.d.). 
Coalition-building methods vary from one case to another. For example, an agency covering a large rural area applies "coalitional planning" to build support among community leaders and public officials who can affect planning. Agency staff analyze power structures to identify influentials and then include them on the governing board, subarea councils, and committees. Another agency creates subarea councils with comittees, subcormittees, and task forces to develop plans, review projects, and advocate change at the local level. Each council has staff who coordinate relations with constituent organizations. Another agency assists and funds groups forming community councils within subareas. These councils help identify local problems, lobby legislators, and support implementation (Checkoway, 1981; Roche, 1981). A third agency targeted under-served groups and traditional nonparticipants, conducted community outreach and medial campaigns, held training sessions on problems and prospects, and formed a coalition which continues to have an impact on the agency and community today (Glenn, Lipschultz, and Sherry, 1981).

\section{Activate People in Planning}

The benefits of citizen participation in planning are well known. For agencies, participation can fulfill legislative mandates, improve communications, provide information, and build support. It also can open up the political process, involve low income and minority citizens, and develop community organizations. For citizens, participation can offer opportunities to gain representation, exercise legal and political rights, and influence policy decisions. Done with knowledge and skill, participation can enhance participatory democracy, improve planning, and build support on which to ground change.

Recent years have witnessed an increase in citizen participation programs and methods employed by agencies, although the overall record has been uneven. Many agencies have expanded the scope of participation, and exceptional ones have sought participation with fervor. But few agencies have adopted singular, driving objectives for participation, favored methods that transfer power to citizens, or used participation to mobilize constituency support. Most planners view themselves as comitted to participation, but work in the face of obstacles and problems of practice that renain. 
Knowledge of participation practice also has increased over time. Agency catalogues count more than forty current or emergent methods, analyze selected methods according to function, and rationalize the design, implementaton, and evaluation of practice (Advisory Commission on Intergovernmental Relations, 1979; Community Services Administration, 1978; U.S. Department of Transportation, 1976). Analysts have studied participation objectives and methods in use, identified major participants and obstacles, and evaluated impacts and factors influencing the field (Burke, 1979; Gil and Lucchesi, 1979; Glass, 1979; Rosenbaum, 1983; Rosener, 1979).

Practitioners have provided perspectives and lessons from practical experience. For example, Creighton (1981) describes steps from empirically based practice to identify participation objectives and publics, formulate alternatives, assess internal and external resources, and match methods to purpose at each stage of planning. This is not to suggest that methods alone can activate citizens and build support. On the contrary, studies suggest that formal methods show little or no association with the quality or impact of participation, while other factors -- including board and staff comitment and leadership -- do correlate with quality participation (Checkoway and O'Rourke, 1983). But they provide lessons for practice nonetheless.

\section{What are the Obstacles?}

There are serious obstacles to building support for planning at the community level and there has been extensive writing on this subject. It is important, however, to recognize obstacles while also embracing the desirability and possibility of change.

It is difficult to build support for planning when agencies lack legitimacy in the community. Private economic interests often act like they should control local planning decisions and resist efforts to get them to share their power with others. Citizens may accept the notion of private control over planning systems and show little support for public intervention. Only a fraction of the general public perceives planning as an activity in which they could participate or knows of the existence or functions of planning agencies (Foley, 1955; Lipsky and Louds, 1976; Riska and Taylor, 1978). Citizens often receive information 
through networks dominated by private interests and hesitate to "intrude" in areas involving private power. The lack of public knowledge and support tends to lower the expectations for planning and reduce the incentives for public initiatives. This is not to suggest that public attitudes toward p!anning agencies necessarily arise from some independent group consciousness or are to be taken for granted. On the contrary, it would be as mistaken to take public attitudes as given as it would be to ignore organized private efforts to shape public attitudes or to reject the possibility that new initiatives could respond and alter the situation. Intervention could make a difference, as private interests have shown for years.

It is also difficult to build support when planners lack knowledge, skills, or attitudes conducive to practice. Studies find only a minority of planners who regard their work as properly or inevitably political, a majority of straightforward technicians who believe they are or should be concerned with objective factfinding and rational analysis of information, and a substantial group who are ambivalent about acting political and who tend to emphasize technical skills as a result of this ambivalence (Baum, 1983). Other studies other studies find planners who stress values of efficiency, economy, and control which often are the antithesis of citizen participation (Aleshire, 1972; Friedman, 1973). They perceive ordinary citizens as lacking knowledge and professional expertise; expect their participation to cause delays in action, expand the number of conflicts, and increase the costs of operatons; and regard their inquiries as a waste of time and distraction from "work" (U.S. House Subcomittee on Health and the Environment, 1978). There are exceptional planners who activate citizens and build support with fervor, but they do not appear typical.

This image has implications for planning research and education. First, most planners do not perceive themselves as political, a situation which could be defined as a problem for research and education to address. Second, a minority of planners are political and their work could provide lessons for others. Third, a substantial group of planners are ambivalent and possible constituents or allies for changing practice. There is no a priori reason why planners could not develop the capacity and skills to build support for their work in the community. Research and education could find excellent opportunities here. 
Some analysts argue that research and education do not prepare people for effective practice. Hemmens, Bergman, and Moroney (1978) survey planning graduates who report that their jobs require analytic, communication, and process skills different from the training received in the schools. Schon, Cremer, Osterman, and Perry (1976) survey other planning graduates who report that key skills in writing, negotiating, influencing, and consulting with clients were not usually available in planning curricula. De Neufville (1983) contends that planning schools agree on no common literature, raise questions which have no answers or produce stale debate, and provide poor instruction to make planning work. She argues that planning theory is inconsistent with experience, irrelevant to application, and frustrates scholars and practitioners.

But it would be as mistaken to blame scholars and educators for not bridging the gap between knowledge and action as it would be to excuse practitioners from their responsibility to apply knowledge that is already available. The issue is not the continuing need to improve knowledge and education, but whether practitioners are willing or able to apply what is already available. Some planners have sought to build support, and implement plans in the face of power, but others, perhaps most, have opted to sit tight and wait for earlier times to return rather than to play a more active role. Dyckman (1983) argues that although planners once may have been concerned with broad social policy, political action, and community leadership, they subsequently became entrenched in government bureaucracies applying instrumental rationality and mechanical skills to projects shaped by authoritarian regimes and powerful private interests. Marcuse (1983) decries the to retreat of some planners from progressive ideals to instrumental or technocratic practice, from long range planning to short range expediency, from the broader public to narrow private interests, and from ordinary citizens to established powerholders. Schon (1983) observes that despite technical innovations in planning -- most planners have not adopted behavior conducive to agency survival.

In the final analysis, planning agencies face the power of private economic interests, which mobilize resources and ongoing organizations, mount campaigns to shape public attitudes, and work to influence, control, or defeat planning. For example, Pines (1982) describes heads of companies developing media campaigns and 
advertising drives against government agency initiatives; conducting economic education and antiregulatory programs in the workplace and classroom; formulating strategy and building coalitions to pack public hearings with witnesses, write speeches for allies, lobby legislators and administrators, and influence decisions. Citizen participation has increased in scope and quality around planning, but private economic interests are often the most active, organized, and influential participants. They challenge planners to respond and alter the situation, but even exceptional efforts still would operate in an imbalanced political arena.

\section{Conclusion}

Planning operates in a changing context in which austerity policies and adversarial power challenge them to recognize sociopolitical change and develop capacity for the years ahead. Planners who want to influence implementation -- and perhaps agency survival -- must go beyond rational models to apply sociopolitical methods to build support for planning at the community level. These include methods to formulate strategy, identify issues, develop constituencies, educate the public, and activate citizens in planning. There are obstacles to practice, but exceptional agencies show possibilities and provide lessons for others.

Building citizen support can help influence implementation at the community level. This does not suggest that the answer to implementation is in these methods alone, for planning operates in an arena which requires more powerful methods than those described here. Nor does it deny that this approach might engender controversy and arouse reaction by groups that may emerge more powerful than before. Nor does it neglect that planning agencies offer only one vehicle to activate citizens and create needed change in the community. There are other means, one or a combination of which may be better ways to bring needed change. In the final analysis, building citizen support for planning at the community level might not make much difference. But then again it might.

\section{REFERENCES}

Advisory Commission on Intergovernmental Relations. Citizen Participation in the American Federal System, Washington: Advisory Commission on Intergovernmental Relations, 1979. 
Alterman, Rachelle. "Implementation Analysis: The Contours of an Emerging Debate," Journal of Planning Education and Research, 3 (Summer 1983), pp. 63-66.

Arnstein, Sherry L. "A Ladder of Citizen Participation," Journal of the American Institute of Planners, 35 (4), 1969, pp. 216224 .

Bardach, Eugene. The Implementation Game: What Happens After a Bill Becomes Law. Cambridge: MIT Press, 1977.

Barkdall, Gerald L. "Involving Constituents in Agency PrioritySetting: A Case Study," Evaluation and Program Planning, 6: $31-37,1983$.

Baum, Howell S. Planners and Public Expectations. Cambridge: Schenkman, 1983.

Baum, Howell S. "Politics and Ambivalence in Planners' Practice," Journal of Planning Education and Research, 3 (Summer, 1983): $13-22$.

Benveniste, Guy. The Politics of Expertise. San Francisco: Boyd and Fraser, 1977.

Beyle, Thad L. and George T. Lathrop, eds. Planning and Politics: Uneasy Partnership. New York: Odyssey Press, 1970.

Bleiker, Hans. Citizen Participation Handbook. Laramie: Institute for Participatory Planning, 1978.

Booth, Heather. Direct Action Organization. Chicago: Midwest Academy, 1977.

Boyer, M. Christine. Dreaming the Rational City: The Myth of American City Planning. Cambridge: MIT Press, 1983.

Bradley, John. "An Educational Approach toHealth Planning," in Citizens and Health Care, supra, 1981.

Bryson, John M. and Andre L. Delbecq. "A Cont ingent Approach to Strategy and Tactics in Planning," Journal of the American Institute of Planners, 45 (April 1979), Pp. 167-179. 
Bryson, John M., R. Edward Freeman, andwilliam D. Roering. "Strategic Planning in the Public Sector: Approaches and Future Directions," Unpublished ms., 1985.

Burchell, Robert W. and George Sternlieb, eds. Planning Theory in the 1980's: A Search for Future Directions. New Brunswick: Center for Urban Policy Research, 1978.

Burke, Edmund M. A Participatory Approach to Urban Planning. New York: Simon and Schuster, 1936.

Carnegie, Dale. How to Win Friends and Influence People. New York: Simon and Schuster, 1936.

Checkoway, Barry. "Citizen Action in HealthPlanning," In Citizens and Health Care: Participation and Planning for Social Change, ed., Barry Checkoway. New York: Pergamon Press, 1981 a.

Checkoway, Barry. "Citizens on Local Health Planning Boards: What Are the Obstacles?," Journal of the Community Development Society, 10 (2), 1979, pp. 106-116.

Checkoway, Barry. "Consumerism in Health Planning Agencies," in Health Planning in the United States: Selected Policy Issues, Washington: National Academy of Sciences Press, $1981 \mathrm{~b}$.

Checkoway, Barry. "Innovative Citizen Participation in Health Planning Agencies," in Citizens and Health Care: Participation and Planning for Social Change, ed. B. Checko way. New York: Pergamon, 1981.

Checkoway, Barry, ed. "New Perspectives on Planning Practice," Journal of Planning Education and Research, 3 (Sumer 1983): Special issue.

Checkoway, Barry. "Public Participation in Health Planning Agencies: Promise and Practice," Journal of Health Politics, Policy and Law 7 (3), 1982b, Pp. 122-133.

Checkoway, Barry. "The Politics of PublicHearings," The Journal of Applied Behavioral Science, 17 (4), 1981 , pp. 566-582. 
Checkoway, Barry. "Two Types of Planning in Neighborhoods," Journal of Planning Education and Research, 3 (Winter 1984), Pp. 102-109.

Checkoway, Barry and O'Rourke, Thomas. "Correlates of Consumer Participation in Health Planning Agencies," Policy Studies Journal, 3 (February 1983), pp. 296-310.

Checkoway, Barry, Thomas 0'Rourke, and DavidM. Macrina. 'Represen tation of Providers in Health Planning Boards," International Journal of Health Services, Vol. 11 (4), 1981 , pp. 573-581.

Clavel, Pieree, John Forester, and WilliamW. Goldsmith, eds. Urban and Regional Planinng in an Age of Austerity. New York: Pergamon Press, 1980 .

Community Services Administration. Citizen Participation. Washington: Community Services Administration, 1978.

Creighton, James L. The Public Involvement Manual. Cambridge: Abt Associates, 1981.

Davidoff, Paul. "Advocacy and Pluralism in Planning," Journal of the American Institute of Planners, 31, 1965, pp. 331-338.

Dluhy, Milan. Social Change: Assessing and Influencing the Policy Development Process at the State and Local Levels, Washington: Aurora Associates, 1981.

Dyckman, John. "Planning in a Time of Reaction," Journal of Planning Education and Research, 3 (Sumer 1983), pp. 5-12.

Feshback, Dan and Takuya Nakamoto. Political Strategies for Health Planning Agencies, in Citizens and Health Care, supra, 1981.

Foley, Donald. "How Many Berkeley Residents Know About Their City's Master Plan?," Journal of the American Institute of Planners 21, 1955, pp. 138-144.

Forester, John. "Planning in the Face of Power," Journal of the American Planning Association, 48, 1982, pp. 67-80. 
Freire, Paulo. Pedagogy of the Oppressed. New York: Seabury Press, 1968.

Friedman, John F. Retracking America: A Theory of Transactive Planning. Garden City, NY: Anchor, 1973.

Gil, Efraim and Enid Lucchesi. "Citizen Participation in Planning," in The Practice of Local Government Planning, ed., Frank So, Washington: International City Managers' Association, 1979.

Glass, James J. "Citizen Participation in Planning: The Relationship Between Objectives and Techniques," Journal of the American Planning Association, 45 (2), 1979, pp. 180-189.

Glenn, John M., Lillian Brandt, and F. Emerson Andrews. Russell Sage Foundation: 1907-1946. New York: Russell Sage Foundation, 1947.

Glen, Karen, Claire Lipschultz, and Susan Barry. "The Consumer Health Advocacy Project," in Citizens and Health Care, supra, 1981.

Godschalk, David R., ed. Planning in Amer ica: Learning From Turbulence. Washington: American Institute of Planners, 1974.

Gordon, Robbie. We Interrupt This Program... A Citizen's Guide to Using the Media for Social Change. Amherst: Citizen Involvement Training Project, 1978.

Goulet, Denis. The Cruel Choice: A New Concept in the Theory of Development. New York: Atheneum, 1973.

Hemmens, George C., Edward M. Bergman, and Robert M. Moroney. "The Practitioner's View of Social Planning," Journal of the American Institute of Planners, April 1978, pp. 181-192.

Joslyn-Scherer, M.S. Communication in the Human Services. Beverly Hills: Sage, 1980 .

Kahn, Si. Organizing: A Guide for Grassroots Leaders. New York: McGraw-Hill, 1980. 
Kasperson, Roger $\varepsilon$. and Myrna Breitbart. Participation, Decentralization and Advocacy Planning. Washington: Association of American Geographers, 1974.

Kimmey, James R. "Technical Assistance andConsultation for Consumers," in Citizens and Health Care, supra, 1981.

Krueckeberg, Donald A. and Arthur L. Silvers. Urban Planning Analysis: Methods and Models, New York: John Wiley, 1974.

Krumholz, Norman. "A Retrospective View of Equity Planning: Cleveland 1969-1979," Journal of American Planning Association $48(2), 1982, \mathrm{pp} \cdot 163-184$.

Lancourt, Joan. Developing Implementation Strategies: Community Organization Not Public Relations. Boston: Boston University Center for Heal th Planning, 1979.

Lipschultz, Claire. Political Action in Health Planning: Building a Consumer Constituency. Bethesda: Alpha Center for Health Planning, 1980.

Lipsky, Michael and Morris Lounds. "Citizen Participation and Health Care: Problems of Government Induced Participation," Journal of Health Politics, Policy and Law, 1 (1), 1976, pp. 85-111.

Lynn, Laurence E. The State and Human Services: Organizational Change in a Political Context. Cambridge: MIT Press, 1983.

Marcuse, Peter. "The Feeble Retreat of Planning," Journal of Planning Education and Research, forthcoming.

Marmor, Theodore R. and James A. Morone. 'Representing Consumer Interests: Imbalanced Markets, Health Planning, and the HSAs," Milbank Memorial Fund Quarterly/Health and Society 58, Spring 1980, pp. 125-165.

Mazmanian, D.A. and J. Nienaber. Can Organizations Change? Environmental Protection, Citizen Participation, and the Corps of Engineers. Washington: Brookings Institution, 1979. 
Mazmanian, Daniel A. and Paul A. Sabatier, eds. Effective Policy Implementation. Lexington: Lexington Books, 1981.

Mueller, C. The Politics of Communications, New York: Oxford University Press, 1973.

O'Rourke, Thomas W. and Mohammed Forouzesh.'Readability of HSAs' Plans: Implica tions for Public Involvement," Health Law Project Library Bulletin, 6 (1), 1981, pp. 23-26.

Peters, T.J., and R.H., Waterman, Jr. In Search of Excellence: Lessons from America's Best-Run Companies. New York: Harper and Row, 1982.

Pines, Burton Yale. Back to Basics: The Traditionalist Movement that is Sweeping Grass-Roots America. New York: William Morrow, 1982.

Riordan, William L. Plunkitt of Tammany Hall: Very Plain Talk on Very Practical Politics. New York: E. P. Dutton, 1963.

Riska, E. and J.A. Taylor. "Consumer Attitudes Toward Health Policy and Knowledge About Legislation," Journal of Health Politics, Policy and Law 3, 1978, pp. 112-123.

Roche, Joseph L. "A Community Organization Approach to Health Planning," in Citizens and Health Care, supra, 1981.

Rosenbaum, Nelson, ed. Citizen participation: Models and Methods of Evaluation. Washington: Center for Responsive Governance, 1983.

Schakowsky, Jan. Coaltion Building. Chicago: Midwest Academy, n.d.

Schon, Donald A. The Reflective Practitioners, New York: Harper and Row, 1982.

Schon, Donald A., Nancy Sheldon Cremer, Paul Osterman, and Charles Perry. "Planners in Transition: Report on a Survey of Alumni of MIT's Department of Urban Studies, 1960-1971," Journal of the American Institute of Planners 42 (2), 1976, pp. 193-202. 
Scott, Mel. American City Planning Since 1890. Berkeley: University of California Press, 1969.

Spiegel, A. D. and H. H. Hyman. Basic Health Planning Methods. Germantown, MD: Aspen Systems Corporation, 1978.

Staples, Lee. Roots to Power: A Manual for Grass-Roots Organizing. New York: Praeger, 1984.

Steiner, George A. Strategic Planning. New York: Free Press 1979.

Strauss, Marvin, C. J. Harten, and M. A.Kempner. "Training of Planning Personnel for Local and State Agencies," Public Health Reports. 91, (January-February 1976), pp. 51-53.

Tait, John L., Janet Bokemier, and Janet Bohlen. Identifying the Community Power Actors: A Guide for Change Agents, Ames: lowa Cooperative Extension Service, n.d.

Texas Municipal League. Building Citizen Support in Texas Cities. Austin: Texas Municipal League, 1975.

Thompson, Frank J. Health Policy and the Bureaucracy: Politics and Implementation. Cambridge: MIT Press, 1981.

Twain, Mark. The Mysterious Stranger, n.d.

U.S. Department of Transportation. Effective Citizen Participation in Transportation Planning. Washington: Government Printing offire, 1976.

U.S. House Subcomittee on Health and the Environment. Hearings on H. R. 10460. Washington: Government Printing Office, 1978.

Welsh, J.C. "Coalition Formation and Development," in Tactics and Techniques of Community Practice, eds., F. Cox, et al. Itasca, IL: F. E. Peacock, 1977. 
Winholz, William G. "Planning and the Public," in Principles and Practice of Urban Planning, eds., William 1. Goodman and Eric Freund. Washington: International City Managers' Association, 1968. 